\title{
Demographic and Socio-Economic Factorts as Determinants of Tax Complaince in Self-Assessment System (Sas) In Akwa Ibom State, Nigeria
}

\author{
Nsima Johnson Umoffong \\ Department of Accounting \\ Faculty of Business Administration, Universiity of Uyo, Nigeria. \\ Etim Osim Etim \\ Department of Accounting \\ Faculty of Business Administration, Universiity of Uyo, Nigeria. \\ Daniel Okon Bassey \\ Department of Accounting \\ Faculty of Business Administration, Universiity of Uyo, Nigeria.
}

\begin{abstract}
The study examined three determinants of voluntary compliance in self-assessment system of tax administration in Akwa Ibom State, Nigeria. This was motivated by the growing need to increase tax revenues generation in developing countries the tax revenue as a ratio of Gross Domestic Product is below the global average and tax administration machinery has been ineffective. Data for the study were collected using a structured questionnaire from respondents registered with the state Board of Internal Revenue determined using Taro Yamene's Statistical Formula. Descriptive and Regression Analyses were adopted for data treatment. The model summary reveals that $\mathbf{8 0 . 8 \%}$ of the variation in Tax compliance is accounted for the variables of perception of equity and fairness, income level and level of education of the tax payers. The ANOVA Summary justifies that the independent variables have significant influence on tax compliance with f-calculated value of 233.763 being greater than the critical f-value of 0.308451 at $P<0.05$. The regression coefficient indicates a positive and significant relationship between perception of equity and fairness $(0.260)$, level of education (0.103) and tax compliance. Income level (0.055) has negative influence on tax compliance. It is recommended that tax authorities should evolve a framework that will motivate, control, sensitize and educate tax payers on voluntary compliance in Self-Assessment system.
\end{abstract}

Keywords: Self-Assessment System, Tax compliance, Equity and Fairness, Education and Income Level. 


\subsection{INTRODUCTION}

The study of tax policy is concerned with the design of a tax system that is capable of financing the necessary level of public spending which has been on the increase; in the most efficient and equitable way possible. In developing economy such as Nigeria that aim at enhancement of economy growth and development as well as becoming integrated with the international economy, tax policy must be a particularly sensitive role. In these economies, the tax system should: (1) Raise enough revenue to finance essential expenditure without recourse to excessive public sector borrowing; (2) Raise the revenue in a way that are equitable and that minimize its disincentive effects on economy activities; and (3) Do so in ways that do not deviate substantially from international norms (Janzi and Zee, 2000).

However, the essence of taxation cannot be achieved without a proper administrative and accounting procedure. This procedure will provide an effective tax legislation that enhances collection and stimulates compliance. Unfortunately, in Nigeria, the establishment of effective and efficient tax system faces some formidable challenges. The first of this challenge is the structure of the economy characterized by large informal setups that make it difficult to impose and collect certain taxes and the limited capacity of the tax administration. At the root of these key challenges lies the compliance issue. Like in most developing countries, tax compliance poses a critical tax challenge to tax administration and also influence the fiscal system vis-a-vis revenue performance. Tax administration can be through Direct-Assessment System (DAS) or Self-Assessment System (SAS). Most countries in the developed and developing economies opted for the Self-Assessment System as a result of acclaimed benefits. These benefits include; taxpayers' precision in calculating their tax liabilities themselves and filing the returns, it saves time as it is done within a stipulated period, it is convenient safe and secure as taxpayers are expected to calculate their tax liabilities at their convenience and the cost of tax collection to the tax authority is low since the burden of calculating the tax liabilities is being shifted to the tax payers.

However, the acclaimed benefits from SAS compliance are a function of a number of variables described as the motivating factors in tax compliance under the self-assessment system of tax administration. These factors may be categorized into: personal or individual factors, socioeconomic factors and demographic factors. Most empirical studies often focus on the individual factors and to some extent the socio-economic factors. For the purpose $f$ this study, we shall examine perception of equity and fairness, income and education levels of taxpayers in the study area. These are a collection of socio-economic and demographic factors.

\subsection{Statement of the problem}

The Nigerian economy is a mono-product economy depending almost solely on crude oil exports revenue hence exposed to the vagaries of International oil market and non-realistic revenue flows from the oil-economy despite the large informal sector of the economy. In part as a consequence of the structure of the economy and in part as the result of over dependence in oil revenues, apt attention is never paid on ensuring a good tax administration that enhance revenue yield to fund public spending. The consequences have been heart provoking outcries by various state governments over their poor financial base. As a consequence, tax revenue as a percentage or ratio of Gross Domestic Product (GDP) for the country as remain very low ranging between 2.9 percent and 4.8 percent from 2005-2015 (International Monetary Fund,2015). This declining trend in tax mobilization as a percentage of Nigeria GDP as a measure of determining the country's tax 
Umoffong, N. J., Etim, E. O., \& Bassey, O. D. (2020). Demographic and Socio-Economic Factorts as Determinants of Tax Complaince in SelfAssessment System (Sas) In Akwa Ibom State, Nigeria. Archives of Business Research, 8(5). 112-136.

mobilization as a percentage of Nigeria GDP as a measure of determining the country's tax mobilization is considered very low compared other developing countries such as Indonesia and Malaysia whose tax revenue as a percentage of GDP were 13.35 percent and 15.3 percent respectively in 2008 (Asian Development Bank 2009). This might be attributed to the problem of tax non-compliance which as become more serious after the implementation of Self-Assessment System in the country. This study, therefore seek to ascertain the influence of select demographic and socio-economic factors as they affect tax compliance in Akwa Ibom State, Nigeria.

\subsection{Objectives of the Study}

The specific objective of this study:

i. Access the socio-economic factor of perception of equity and fairness on voluntary compliance in Self-Assessment System in the study area.

ii. Ascertain the demographic factor of income level influence on voluntary compliance in Self-Assessment System in the study area.

iii. Examine the demographic factors of level of education influence on voluntary compliance in Self-Assessment System in the study area.

\subsection{Research Questions}

The following research questions stated in line with the research objectives would be address in the study;

i. Does the socio-economic factor of perception of equity and fairness have any influence on voluntary compliance by taxpayers in Self-Assessment System in the study area?

ii. How does demographic factor of income level influence on voluntary compliance in SelfAssessment System in the study area?

iii. What is the relationship between the demographic factor of level of education of taxpayers and voluntary compliance in Self-Assessment System in the study area?

\subsection{Research Hypotheses}

The following hypotheses stated in null form are formulated and tested in the course of the study: $\mathrm{Ho}_{1}$ : The socio-economic factor of perception of equity and fairness does not significantly influence voluntary compliance by taxpayers in Self-Assessment System in the study area.

$\mathrm{Ho}_{2}$ : Income level of taxpayers does not significantly influence voluntary compliance by taxpayers in Self-Assessment System in the study area.

$\mathrm{Ho}_{3}$ : Level of education of taxpayers does not significantly influence voluntary compliance by taxpayers in Self-Assessment System in the study area.

It is expected that the findings of the study would be relevance to the relevant tax authorities in identifying those factors determining voluntary tax compliance and putting in place informed strategies to booster compliance by individual taxpayers. Those conducting further studies in related area, tax administrators, consultants and academic would benefit from the study outcome.

For organizational purposes, the rest of the paper cover review of related literature in section 2 , methodology and design of the study in section 3, results and finding in section 4 and finally section 5 focusing on summary and conclusion. 


\subsection{Review of Related Literature}

The review of related literature is carried out under three sub-headings - conceptual review, theoretical framework and review of empirical studies.

\subsection{Conceptual Issues}

\subsubsection{Concept of Taxation}

The social and economic development of any country is a function of the amount of revenue generated for the provision of infrastructure in the given country. Government does some good things in this direction, indeed, having a government seems critical to having a prosperous and well-order society. Yet government use resources, and a means must be found in capturing these resources from private uses. While a variety of means are used debt financing, printing money, expropriating private assets, mandating private performance of governmental objectives, the assessment of user charges-by far the most important way that we pay government is through taxation (Etim and Nweze, 2015). Azubike (2009) is of the view that tax is the major player in the society of the world.

The tax system in an opportunity for government to collect taxes and the most effective means of mobilizing a nation's internal resources and lends itself to creating an environment conducive to promoting voluntary compliance to payment, though tax are compulsory levy. Government use tax proceeds to render their traditional functions, such as provision of public goods, maintenance of law and order, defend against internal and external aggression, regulation of trade and business production of certain goods and services, protection of infant industries, curbing inflation, reduce income inequalities, among others. This lofty functions cannot be realize by government if taxpayers do not comply either directly or indirectly. Thus, at the root of efficient tax administration is the issue of tax compliance particular in the Self-Assessment System (SAS).

\subsubsection{Tax Compliance}

Kirchler (2007) stated that tax compliance might be voluntary or enforced. Voluntary compliance is made possible by the trust and cooperation between tax authority and taxpayer and it is the willingness of the taxpayers on his own to comply with the tax authority's and directive and regulations. However, in the presence of distrust and lack of cooperation between tax authority and taxpayer, which creates tax hostilities, authorities can enforce compliance through the treat and application of audit and fine. AIM, Jackson and Milliron (1991) define tax compliance as the reporting of all income and payment of all taxes by fulfilling the provision of laws, regulation and court judgments.

Another definition of tax compliance is a person's act of filling their tax returns declaring all taxable income accurately and disbursing all payable taxes within the stipulated period without having to wait for follow-up action from the authority (Singh, 2003).

Some authors viewed the compliance from a different perspective, for example, Allingham and Sandmo (1972) described tax compliance as an issue of reporting an actual income and also claimed that tax compliance behaviour was influenced by a situation whereby taxpayers have to make a decision, under uncertainty, that is, either the taxpayer would enjoy tax savings due to under-reporting incomes or have to pay tax on the undeclared amount at a penalty rate which is higher than what they would have paid had the income been fully declared at the right time. 
Umoffong, N. J., Etim, E. O., \& Bassey, O. D. (2020). Demographic and Socio-Economic Factorts as Determinants of Tax Complaince in SelfAssessment System (Sas) In Akwa Ibom State, Nigeria. Archives of Business Research, 8(5). 112-136.

Evaluating the different definitions of tax compliance, one can easily deduce that it shows the degree of taxpayer's readiness to abide to the tax rules of his country by declaring his income, filling tax return and paying the due in a timely manner.

\subsubsection{Determinants of Tax Compliance}

Jackson and Milliron (1986) listed several factors that have influence compliance as described by various researchers. This factors include: individual, socio-economic and demographic factors with further sub-classifications. Ceteris paribus, for the purpose of this study, we examine: perception of equity and fairness, income level and level of education of the taxpayers as they influence SelfAssessment System.

\subsubsection{Perception of Equity and Fairness}

One of the main principles of a good tax system and administration is equity and fairness. This can be perceived via two dimension; horizontal equity (People with the same income or wealth bracket paying the same amount of taxes) and vertical equity (tax paid should increase with increase in the amount of taxable income). The driving force behind equity is the notion that those who are not. Wenzel (2003) suggested three areas of fairness from the taxpayers' point of view;

i. $\quad$ Distributive justice (viewed as the exchange of resource that is benefit and cost).

ii. Procedural Justice (viewed as the process of resource distribution),

iii. Retributive Justice (viewed as the appropriateness of sanctions when norm breaking occur).

In distribution justice, an individual is concerned about the fairness of their actions and want to be treated in relation to the merits, efforts and needs (Kirchler et.al, 2008). If the taxpayer feels that the tax burden is higher than other people within the same income group, the tax compliance will properly decrease. Taxpayers want a fair treatment of their group relative to other income groups. Is a specific group perceived that their tax liability is higher than other groups, then noncompliance might occur among the group member (Spicer and Becker, 1980). At a society-wide level, tax compliance is less likely if the perception is held that the tax system is unfair, wide-scale tax non-compliance is likely to occur (Allingham and Sandmo, 1972, as cited in Etim and Nweze, 2015). In contrast, if the society perceive that the tax system is equitable and fair, voluntary compliance is expected to increase.

With regard to the procedural justice, the main element for perceived fairness are neutrality of procedural used, trustworthiness of the tax authorities, politeness, dignified and respectful treatment of taxpayers as individuals or otherwise (Tyler and Lind, 1992). On retributive justice, unreasonable intrusive audits and unfair penalties lead to stressful and dissatisfied taxpayers. Unfavourable retribution justice perception could lead to non-compliance behaviour and consequently increase evasion. However, studies on this factor have been conducted by different researchers such as Fatt and Khin (2012), and Oladipupo (2016), give conflicting outcomes, thus, this study to provide empirical evidence from the present study.

\subsubsection{Income Level}

Jackson and Milliron (1986) found that income level have a mixed and unclear impact on compliance, a theory also supported by Christian and Gupta (1993) and Hite (1997). Although, Jackson and Milliron did not clearly elaborate on the reason for this finding, it is presumed that the 
endogenous tax regulation among countries might contribute to the consistent finding. For example, progressive tax rates might encourage high income groups to evade tax rather than lower income group because their (high income group) tax rates and taxable income are high, thus making the tax liabilities much higher than those in the lower income group. For example, Wallschutzy (1984) in his study in Australia and LOO (2006) in her study in Malaysia found that high income earners were less complaint. This study have evidenced that income level have significant impact on compliance.

In contract, high income earners are likely to be more complaint rather than lower income earners, as suggested by Wearing and Heady (1997) and Torgler (2007). In a country where the income redistribution is not satisfying, higher income group tend to evade more (Mohani, 2001). This is because high income earners might feel the tax system is not treating the fairly.

According to Chan, Trountman and O'Bryan (2000), non-compliance opportunities based on income level can be affected directly or indirectly through attitudes and perception. Chan et.al, (2000) results suggest that income level is unrelated to compliance among US and Hong Kong taxpayers. Jackson and Milliron (1986); Roth et-al (1989) also suggest that the direct relationship between income level and tax compliance remain unclear. Despite the positive and negative association of income levels with tax compliance, there are studies that found insignificant results that should be noted. For example, Park and Hyn (2003) in their experiment in South Korea found that income levels had no significant effect on tax compliance. These conflicting results require further empirical investigation, which this study seek to further examine in the study area.

\subsubsection{Level of Education}

One of the fundamental ways to increase public awareness is for taxpayers to have knowledge about taxation and this can be achieved through education (Mohani, 2001). In Self-Assessment System, the level of education received by taxpayers is an important factor that contributes to the understanding of tax requirements, especially regarding registration and filling. Richardson (2008) observed that general education level is significantly related to tax compliance. High awareness by the taxpayers would encourage them to fulfill their obligations to register as taxpayers, reporting and paying taxes properly as forms of natural and civic responsibility. Tax non-compliance had been on the rise because most citizens and taxpayers do not have understanding of what tax laws means and why system is structured and administered as it is (Braithwaite, 2007).

Cham et.al (2000) also postulated that greater education is directly linked to a likelihood of compliance. The argue that educated taxpayers may be aware of non-compliance opportunities, but they have better understanding of the tax system and their higher level of moral development will promote a more favourable taxpayer attitude and therefore greater compliance. They also suggested that those with a higher level of education are more likely to have a higher level of moral development and good attitudes towards compliance and thus will tend to comply more.

In respect to the level of education and it influence on taxpayers' compliance, there are several findings evident in the literature. For example, Beck and Davis (1991) found a positive relationship between education and non-compliance, which was consistent with the finding of Write and Woodbury, (2011). 
Umoffong, N. J., Etim, E. O., \& Bassey, O. D. (2020). Demographic and Socio-Economic Factorts as Determinants of Tax Complaince in SelfAssessment System (Sas) In Akwa Ibom State, Nigeria. Archives of Business Research, 8(5). 112-136.

Lubian and Zarri (2011) argued that education is an important determinant in tax compliance, as schooling provides an important channel through which ethical principles can be disseminated in the community and the magnitude of this effect increases with the level attained. Although tax compliance has strong affective components, education can still play a major role in improving and maintaining tax compliance as public enlightenment and campaigns by tax authorities with regards to their civic responsibility and gains from such can influence the rationalization process of an individual as better information is provided. In such conditions, the potential for an increased level of tax compliance resulting from access to accurate and timely information may be enhanced. Education is a powerful tool for increasing taxpayers' compliance by strengthening the feelings of identity, reciprocity, fairness and procedural justice. Torgler and Schneider (2007) noted that certain fiscal knowledge helps put into account the connection between taxes laws and fiscal connection and this would be in a better position to assess the degree of compliance.

While education level becomes more important in increasing tax compliance across countries, Mohani (2001) suggested that one of the measures to increase voluntary compliance is by arriving that taxpayers have a certain level of qualifications, ability and confidence to exercise their tax responsibility. In contrast, the study by Richardson (2008) reveals that there is a negative association between education level and compliance. With a potential increase to compliance as education level increase, it worth examining those variables in the study area.

\subsubsection{Self-Assessment System}

In a Self-Assessment System, a taxpayer is required to assess and accurately calculate his tax liability using a tax return form in which he declares must then be filed with tax authority together with a payment for the tax liabilities computed on the said return. Under Self-Assessment System, the tax authority's responsibility, partiality on assessing the tax return and determining the liabilities have been shifted to taxpayer duly to declare all the necessary particulars pertaining to their income and expenses for that particular year of assessment and submit the necessary returns together with all required supporting documents to the tax administrators. It is then the tax administrator's duty to assess all tax returns and issue notice of tax stating the tax liability.

In a developed country like United Kingdom, the objective of SAS like every other developed countries was to make the tax system simpler, easier and fairer to taxpayers, to make it possible for the Inland Revenue to accept the statement of Account without further review and to allow taxpayers to pay the right amount of taxes at the right time without intervention by the Inland Revenue (IR) (LOO, 2006). In addition, SAS was expected to allow taxpayer to understand and to have more control over their own tax problem, and eventually open up ways for further reforms aimed at simplifying, unifying and improving the system of personal between taxpayers and tax authorities (Lymer and Oats, 2008). But in a developing country like Malaysia, the mission of SAS set by the government is to collect taxes for the nation at a minimum cost, to remove compliance and to institute effective enforcement (Kasipillai, 2001; Loo, 2006). To accomplish this mission, a threefold objective was established:

$i$ to assess and collect the correct amount of revenue as provided under the law in the most effective manner at a minimum cost.

ii to instill public confidence in the fairness and integrity of the tax system.

iii to encourage voluntary compliance. 
Based on the mission and objectives of SAS from various countries who have adopted the system to date, it seems that voluntary compliance, administrative efficiency and improving fairness and equity are the key motivation for introduction of SAS. LOO (2006) also claims that, the reasons for implementing SAS are to simplify the tax collection system and increase voluntary compliance. Therefore, in order to correct this system into a meaningful tax mechanism compared to the previous Direct Assessment System (DAS), the principles of operation must be created and implemented so that the SAS can be operated efficiently.

\subsection{Theoretical Framework}

This study is guided by the psychology theory of proportion. This theory as originally developed by a renowned Psychologist, Daryl Bem in 1960 states that taxpayers are influenced to comply with their tax obligations by psychological factors such as attitude, ethics and social norms. This theory is seen as counter-intuitive. It also assumes that a person's personality and attitudes drive their actions. In simple terms, it illustrates that "we are what we do". It focuses on the taxpayers' morals and ethics. It suggests that a taxpayer may comply even when the probability of detection is low, based on his state of mind and behavioural pattern. The theory also lays emphasis on changing individual attitudes towards tax systems (Lewis, 1982).

The underlying challenge is that any behavior may represent a multiplicity of attitudes and that tax mentality (person's willingness to pay tax) appears to be an important construct with more than one dimension. Song and Yarborough (1978) found that taxpayers with higher fiscal knowledge had a higher tax ethic than those with lower fiscal knowledge.

\subsection{Empirical Review}

The most important issue in successful implementation of Self-Assessment System of tax is the level of compliance by taxpayers. In some developed and developing economies like Australia, Canada, United Kingdom, Malaysia and Indonesia, several studies have been conducted to examine, evaluate and assess the views and experiences of taxpayers and tax authorities in SAS implementation. Some of the select studies are reviewed in this section of the paper.

Spicer and Lundstedt (1976) studied "Understanding Tax Evasion in Belgium". They adopted a survey model with regression analysis. The findings based on the analysis elucidate that higher income earners pay more tax than lower income class. They found that income level is positively corrected to tax compliance.

Lewis (1982) in his study on "Psychology of Taxation in Rwanda", mentioned that more complexities in tax compliance would arise if one possesses a higher level of education. Whereby, with more understanding of tax system, the taxpayer may misuse the knowledge to search for weaknesses and Loopholes in the tax system and try to evade tax.

Witte and Woodbury (1985) conducted a study on "What we know About the Factors Affecting Compliance and Tax Laws" using a one-way ANOVA. They found a positive relationship between education level and voluntary compliance in USA. They suggested that an educated taxpayer will have a certain fiscal knowledge that will help him put to account the benefit of paying taxes. They posited that education may influence an individual in his or her decision towards tax compliance. This is because, people can comprehend tax laws better with high level of education, hence, become 
Umoffong, N. J., Etim, E. O., \& Bassey, O. D. (2020). Demographic and Socio-Economic Factorts as Determinants of Tax Complaince in SelfAssessment System (Sas) In Akwa Ibom State, Nigeria. Archives of Business Research, 8(5). 112-136.

more compliant as they realize their obligations and duties towards the government and even towards the country. Harris (1989) did a study on the "Effect of Type of Tax Knowledge on Individual's Perception of Fairness and Compliance in United States of America". He adopted an Error Correction Model (ECM) and found that perception to equity and fairness significantly influences compliance. He posited that taxpayers appreciate fair treatment of their group compared to other income groups. If a particular group realizes that their tax liability is higher than other groups, it might lead to non-compliance among the group.

Kasipillai (2001) revealed from a case-study in New-Zealand on "Understanding Self-Assessment: Taxpayers' Perspective", that tax compliance behaviour is hardly influenced by ethics and attitude. He identified that all trust variables are positively correlated with tax morals but negatively corrected with corruption.

Ritsema, Thomas and Ferrier (2003) revealed that education is very important in increasing tax compliance in any country. They suggested that one of the key to ensuring compliance is to have the taxpayer attain some level of education. This they noted with an experimental Survey on "Economic and Behavioural Determinants of Tax Compliance in Arkansas". They concluded that level of education will give the taxpayer the confidence and capacity to exercise their tax responsibility without any enforcement. This they said can motivate the taxpayer as better information is provided and assimilated. However, Porcano (1988) found no evidence to prove that the level of education affect tax compliance level, as none of the t-test showed significant difference in his study.

Wilson and Sheffin (2005) used the USIRS taxpayers' compliance measurement program data and divided the sample into moral and immoral taxpayers. Moral taxpayers were those who did not tolerate evasion of low amount, whereas immoral taxpayers were those who have favourable attitudes towards evading higher amount. Immoral taxpayers were found to be less honest than moral taxpayers. When taxpayers considered the tax system to be "very fair", they were 5 percent more likely to be honest as compared to those perceiving the tax system to be "fair". Moreover, Immoral people were likely to cheat if they had a higher income or, were self-employed. So at all times, low compliances is imminent if the taxpayers perceive that the tax system is unfair. They recommended a robust inclusion of both moral and immoral taxpayers in the tax system planning.

Loo (2006) conducted a study on the "Behaviour of Taxpayers Compliance in Self-Assessment System". He used an analytical design to determine the level of compliance among the income earners. He conducted this study in Malaysia and found that, higher income earners were less complaint. This study evidenced that income level has a significant impact on taxpayers voluntary compliance.

Nzotta (2007) in his study on "Tax Evasion Problem in Nigeria" formed that lack of tax knowledge through tax education has resulted in tax non-compliance. He posited that the level of education received by taxpayers is an important factor that contributes to the understanding of tax processes and requirements especially as it relates to registration and filing of returns. He arrived at this using multiple regression analysis which revealed a positive correlative between education and tax compliance. 
Kirchler et-al; (2008) examined the fairness and equity of Self-Assessment System in Uganda with a study on "Enforced vs Voluntary compliance". They adopted a survey model and perceived it via two dimensions; the horizontal equity (where people with the same income or wealth brackets should pay the same amount of taxes) and vertical equity (where the taxes paid increase with increase in the amount of taxable income). Their empirical framework for fairness consideration suggest different of fairness; distributive justice (referring to exchange of resource, i.e. cost and benefit), procedure justice (referring to the process of resource distribution), and the retributive justice (referring to perceived appropriateness of sanctions in the case of norm-breaking).

Lubian and Zarri (2011) found that education is an important determinant of tax compliances schooling provides an important channel through which ethical principles can be disseminated. They revealed this in a study on "Happiness and Tax Morale in Verona", using descriptive survey method. They concluded that education is positively correlated with tax compliance.

From the view of foregoing literature, several studies have been conducted with inconsistent results of impact of determinants of tax compliance. This study is therefore carried out to contribute the empirical evidence on the on-going debate on Self-Assessment System of tax administration determinants in the study area.

\subsection{Methodology and Design of the study}

This section discusses the methodological issues in the study. It deals with research design, population and sample of the study, research instrument; reliability and validity, model specification and data analysis technique.

\subsection{Research Design}

Survey design is adopted for this study involving the use of structured questionnaire to gather data from the sampled population drown from registered Micro, Small and Medium Enterprises (MSMEs) operators with the Akwa Ibom State Internal Revenue Services (SBIRS) as at the end of 2019 fiscal year.

\subsection{Population and Sample of the study}

The population of this study consisted of 3800 MSMEs Operators registered with the state tax authority at the end of 2019 fiscal year. This population excludes the public servants assessed under the Pay-As-You-Earn (PAYE) basics, but those involved on the Self-Assessment System (SAS) of tax administration. Taro Yamene's statistical formula is used to draw a sample size of 400 taxpayers. The formular is given as:

$$
\mathrm{n}=\frac{N}{1+N(e)} 2 \text {; }
$$

Where; $\mathrm{n}=$ Sample size; $\mathrm{N}=$ population; e=error term (5\%), and I=Constant.

The 400 taxpayers were purposively and systematically selected and administered with the questionnaire.

\subsection{Research Instrument}

The research instrument is a structured questionnaire designed and validated by experts in test and measurement using Likert Scale with five points Sealing from 5 points for strongly Agreed to 
Umoffong, N. J., Etim, E. O., \& Bassey, O. D. (2020). Demographic and Socio-Economic Factorts as Determinants of Tax Complaince in SelfAssessment System (Sas) In Akwa Ibom State, Nigeria. Archives of Business Research, 8(5). 112-136.

1 point for Strongly Disagreed (see appendix for details). The reliability coefficient obtained from the pre-test of the instrument was as shown on the Table 3.1.

Table 3.1 Reliability Statistic

\begin{tabular}{|l|l|}
\hline No of Items & Cronbach's Alpha \\
\hline 32 & 0.946 \\
\hline
\end{tabular}

Source: Researchers' Computation, 2020 using SPSS.20

\subsection{Model Specification}

The variables used in this study are expressed in the following econometric model which is adopted to test the relationship between the dependant and independent variables.

$$
\begin{aligned}
& \mathrm{Y}=\mathrm{f}\left(\beta_{0}+\beta_{1} \mathrm{X}_{1}+\beta_{2} \mathrm{X}_{2}+\beta_{3} \mathrm{X}_{3} \ldots \ldots+\beta_{\mathrm{n}} \mathrm{X}_{\mathrm{n}}+\epsilon \ldots \ldots \text {...equation } 3.1\right. \\
& \text { Where; } \\
& \qquad \begin{array}{l}
\mathrm{Y}=\text { Dependent Variable } \\
\mathrm{F}=\text { Functional Notation } \\
\mathrm{B}_{\mathrm{o}}=\text { Constant } \\
\mathrm{X}_{1}-\mathrm{X}_{\mathrm{n}}=\text { Independent Variables } \\
\\
\beta_{1}-\beta_{\mathrm{n}}=\text { Coefficient of } \mathrm{X} \\
\epsilon=\text { Error term }
\end{array}
\end{aligned}
$$

For the purpose of this study, our model in linear form is expressed as:

$$
\text { TAXCOMP }=\propto+\beta_{1} \text { EQIFAR }+\beta_{2} \text { INCOM }+\beta_{3} \text { EDU }+\epsilon \ldots \ldots . . . \text { Equation } 3.2
$$

Where;

TAXCOMP $=$ Tax compliance

EQIFAR = Perception of Equity and fairness

INCOM= Income level

EDU $=$ Level of Education

$\epsilon=$ Error term

This model is used to test the three hypotheses of the study. The dependent and independent variables and the a priori expectation is stated as follows:

Table 3.2 Dependent and Independent Variables and Aprior Expectation

\begin{tabular}{|l|l|l|l|}
\hline S/N & VARIABLES & TYPE & $\begin{array}{l}\text { 'APRIORI' } \\
\text { EXPECTATION }\end{array}$ \\
\hline 1. & Tax Compliance & Dependent & - \\
\hline 2. & $\begin{array}{l}\text { Perception of Equity and } \\
\text { Fairness }\end{array}$ & Independent & Positive \\
\hline 3. & Income Level & Independent & Negative \\
\hline 4. & Level of Education & Independent & Positive \\
\hline
\end{tabular}

Source: Researchers' Compilation, 2020

\subsection{Estimation Technique}

Regression analysis and Descriptive Statistics is adopted for this research were tested at $5 \%$ level of significance. A null hypothesis is rejected if the probability value is greater than $0.05(\mathrm{P}<0.05)$. 
That is, if the calculated F-Statistics at 5\% level of significance is greater than the tabulated or critical F-statistic, the null hypothesis will be rejected, otherwise accept.

\subsection{RESULTS AND DISCUSSION}

This section attempts to present the data used for this study and the discussion of the results of our analysis.

\subsection{Data presentation and analysis}

The details of data presentation, analysis and discussion of findings are done under this section. In conducting this study, a total of 400 copies of questionnaire were administered to the select respondents. The response rate is persecuted on Table 4.1

Table 4.1: Questionnaire administration and Response Rate.

\begin{tabular}{|l|l|l|}
\hline Copies Administered & Copies Returned & Response Rate \% \\
\hline 400 & 389 & 97.25 \\
\hline
\end{tabular}

Source: Field Survey, 2020.

From the Table 4.1, out of the 400 questionnaire copies administered to selected respondents, 389 representing approximately 97\% response rate were returned with 11 (about 3\%) copies not returned. The validly filled copies are used for the analyses.

Table 4.2: Educational Level of the Respondents

\begin{tabular}{|l|l|l|l|l|l|}
\hline & $\begin{array}{l}\text { Highest } \\
\text { Qualification }\end{array}$ & Frequency & Percent & $\begin{array}{l}\text { Valid } \\
\text { Percent }\end{array}$ & $\begin{array}{l}\text { Cumulative } \\
\text { Percent }\end{array}$ \\
\hline & SSCE & 39 & 10.0 & 10.0 & 10 \\
\hline Valid & ND/NCE & 138 & 35.48 & 35.48 & 45.48 \\
\hline & HND/B.Sc & 154 & 39.60 & 39.60 & 85.10 \\
\hline & POST GRADUATE & 58 & 14.9 & 14.90 & 100.0 \\
\hline & TOTAL & 389 & 100.0 & 100.0 & \\
\hline
\end{tabular}

Source: Researches computation, 2020 Using SPSS.20

The result shown on Table 4.2 explains the educational background of the sampled population surveyed for the study. The respondents with Senior School Educational Certificate (SSCE) are 39(10\%), National Diploma)/ National Certificate of Education (ND/NCE) 138(35.48\%), Higher National Diploma/Bachelors' Degree (HND/B-Sc) 154(39.60\%) and Post-graduate qualification 58(14.9). This result form the premise upon which further analysis is carried out that the respondents have an understanding of the subjects of taxation and tax compliance.

Table 4.3: Number of years in Business operation.

\begin{tabular}{|l|l|l|l|l|l|}
\hline & & $\begin{array}{l}\text { Frequenc } \\
\mathbf{y}\end{array}$ & $\begin{array}{l}\text { Percen } \\
\text { t }\end{array}$ & $\begin{array}{l}\text { Valid } \\
\text { Percent }\end{array}$ & $\begin{array}{l}\text { Cumulativ } \\
\text { e Percent }\end{array}$ \\
\hline & Below 5 years & 38 & 9.8 & 9.8 & 9.8 \\
\hline & 5-10 years & 57 & 14.7 & 14.7 & 24.5 \\
\hline Valid & 11-15 years & 117 & 30.1 & 30.1 & 54.6 \\
\hline & 16 years and above & 177 & 45.5 & 45.5 & 100.0 \\
\hline & Total & 389 & 100.0 & 100.0 & \\
\hline
\end{tabular}

Source: Researchers' computation, 2020 using SPSS 20. 
Umoffong, N. J., Etim, E. O., \& Bassey, O. D. (2020). Demographic and Socio-Economic Factorts as Determinants of Tax Complaince in SelfAssessment System (Sas) In Akwa Ibom State, Nigeria. Archives of Business Research, 8(5). 112-136.

The number of years the respondent have been in business operations is given on Table 4.3. Those who have spent less than 5 years in their business were 38 (9.8\%) 5-10 years 57 (14.7\%), and 1115 years 117 (30.1\%), while 16 year about 177 (45.5\%). This indicates that most of the respondents are experienced in their trade and have engage in the tax payments for some years.

\subsection{Test of Hypotheses}

The hypotheses of the study are tested using Linear Regression Analysis using result on Table 4.4 to 4.6

Table 4.4 Model Summaryb

\begin{tabular}{|c|c|c|c|c|}
\hline Model & R Square & $\begin{array}{l}\text { Adjusted R } \\
\text { Square }\end{array}$ & $\begin{array}{l}\text { Std. Error of } \\
\text { Estimate }\end{array}$ & Durbin-Watson \\
\hline 1 & $.901^{\mathrm{a}} .811$ & .808 & 1.74649 & 1.493 \\
\hline \multicolumn{5}{|c|}{$\begin{array}{l}\text { a. Predictors: (Constant), LEVEL OF EDUCATION, INCOME LEVEL, PERCEPTION OF EQUITY AND } \\
\text { FARNESS. } \\
\text { b. Dependent variable: TAX COMLIANCE }\end{array}$} \\
\hline
\end{tabular}

Source: Researchers Computation, 2020 using SPSS.20

Table 4.5 ANOVA ${ }^{\mathrm{a}}$

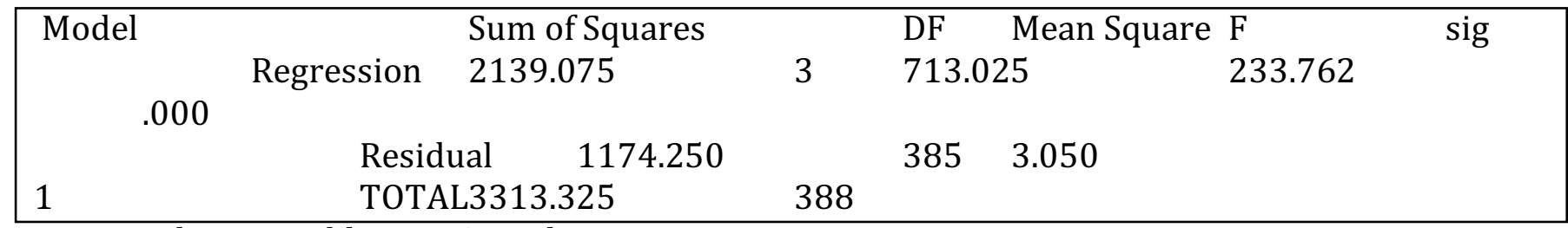

a. Dependent Variable: Tax Compliance

b. Predictors: (Constant), LEVEL OF EDUCATION, INCOME LEVEL, PERCEPTION OF EQUITY AND FAIRNESS

Source: Researchers computation, 2020 using SPSS.20

Table 4.6 Estimates of the Regression Model Parameters

\begin{tabular}{|c|c|c|c|c|}
\hline \multirow{2}{*}{ Model $_{t}$} & \multicolumn{3}{|c|}{ Understanding Coefficients } & \multirow[t]{2}{*}{ Standardized } \\
\hline & & & & \\
\hline & B & Std. Error & $\begin{array}{l}\text { Coefficie } \\
\text { Beta }\end{array}$ & \\
\hline (Constant) & 3.173 & .466 & & 6.806 .000 \\
\hline Perception of Equity and fairness & .227 & .048 & .265 & 4.479 .000 \\
\hline Income Level & -.052 & .025 & -.055 & -2.066 .039 \\
\hline Level of Education & .103 & .043 & .103 & $2.426 \quad 0.16$ \\
\hline Donondont & OMPL & ANCE & & \\
\hline
\end{tabular}

Source: Researchers computation, 2020 using SPSS.20

\section{Test of Hypothesis 1}

The hypothesis I states that the socio-economic factor of perception of equity and fairness does not significantly influence voluntary compliance by taxpayers in Self-Assessment System in the study area. The result of the analysis is shown on Table 4.6. in line with the decision rule of the study, the null hypothesis is rejected because the calculated $t$-value of 4.479 is greater than the critical value 
of 1.966 at $5 \%$ significant level. The beta coefficient of 0.265 implies that $26.5 \%$ of the variation in tax compliance is accurate for by perception of equity and fairness.

\section{Test of Hypothesis 2}

The hypothesis 2 states that income level of taxpayers does not significantly influence voluntary compliance in Self-Assessment System in the study area. The result of the analysis is shown on Table 4.6.

In line with the decision rule of the study, the null hypothesis is accepted because the calculated tvalue of 1.966 at $5 \%$ significance level. The beta coefficient of -0.055 implies that $-5.5 \%$ of the variation tax compliance is accounted for by income level.

\section{Test of Hypothesis 3}

The hypothesis 3 states that level of education of taxpayers does not significantly influence voluntary compliance in Self-Assessment System in the study area. The result of the analysis is shown in the Table 4.6. In line with the decision rule, the null hypothesis is accepted 5\% significant level since the calculated t-value of 2.426 is greater than the critical value of 1.966 . The beta coefficient of 0.103 which implies that $10.3 \%$ of the variation in tax compliance is accounted for by level of education of taxpayers.

\subsection{Discussion of Findings}

The model estimate based on the model specification of the study is given thus;

TAXCOMP. $=\&+\beta_{1}$ EQIFAR $+\beta_{2} \mathrm{INCOM}+\beta_{3} \mathrm{EDU}+\epsilon$

This is:

TAXCOMP $=3.173+0.260$ EQIFAR $-0.055 \mathrm{INCOM}+0.103 \mathrm{EDU}+0.466$

The result of the analysis shown on Table 4.6 reveals the above stated coefficients. The result revealed that perception of equity and fairness have a significant influence on voluntary compliance in Self-Assessment System in the study area. The influence of perception of equity and fairness stood at $0.260(26 \%)$ culling from the beta coefficient analysis. This implies that $26 \%$ of the variation in voluntary compliance is accounted for by taxpayers' perception of equity and fairness. The positive influence suggests that a fair and equitable tax system will encourage voluntary compliance. This result is in agreement with the taxpayers was found to be significant in influencing voluntary compliance in Self-Assessment System in the study area. This indicated by the beta coefficient of $-0.055(-5.5 \%)$.

The implication of this finding is that the higher the income levels of the taxpayer, the lower the level of voluntary compliance in Self-Assessment System. This can further be explained to be true by the fact that higher income earners can afford the services of tax consultants who may collide with them to either evade or avoid the payment of taxes. This finding was supported by the study of Wallschutzy (1984) who concluded that higher income earners were less compliant in Australia. The level of education of the taxpayers significantly influences voluntary compliance in SelfAssessment System in the study area. The analysis indicated by the beta coefficient of 0.103 $(10.3 \%)$ implies variation in voluntary compliance in Self-Assessment System is accounted for by level of education. The implication of this findings is that the higher the level of education, the higher the level of voluntary compliance in Self-Assessment System. This is supported by the fact 
Umoffong, N. J., Etim, E. O., \& Bassey, O. D. (2020). Demographic and Socio-Economic Factorts as Determinants of Tax Complaince in SelfAssessment System (Sas) In Akwa Ibom State, Nigeria. Archives of Business Research, 8(5). 112-136.

that higher education potentially increase compliance as educated taxpayers may be more informed and aware of their responsibility, as well as sanctions to be imposed if they were not complaint with the tax laws. This finding is contrary to the findings of Richardson (2008) who found out that there exist a negative association between education level and tax compliance.

\subsection{Summary, Conclusion and Recommendations}

The study was undertaken to assess the implications of the tax compliance determinants perception of equity and fairness, income level and level of education on the Self-Assessment System of tax administration in Akwa Ibom State, Nigeria. Survey research design was adopted involving the design and administration of structured questionnaire to elicit responses from the sampled population studied. From the results, the following summary, conclusion and recommendations are made:

i Socio-economic and demographic factors of perception of equity and fairness, income level and level of education have significant influence on tax compliance in Self-Assessment System in the study area.

ii While perception of equity and fairness and level of education have positive and significant influences on tax compliance in Self -Assessment System ( 0.260 and 0.103 coefficients), income level ( -0.062 coefficient) has a negative influence on tax compliance in Self-Assessment System. From the above, the following recommendations are made:

i Relevant tax authorities and other agencies should intensify effort to making taxpayers increasingly aware of the equitable and fair treatment of each income groups to avoid some form of distributive justice.

ii Government or relevant tax authorities should constantly organize awareness campaigns, seminars, symposiums, among others for taxpayers in seeking to improving the general tax compliance knowledge of taxpayers in order to acquaint them with the existing tax compliance procedures and regulations.

Also, it is suggested that a comparative study of tax compliance determinants in various states of the federation be carried out to enhanced a comprehensive tax reforms in the country.

\section{References}

Allingham, M. G. And Sandmo, A. (1972). Income tax evasion: A theoretical analysis. Journal of Public Economics, 1(3\&4):323-383

Alm, J, Jackson, B. and Mckee, M. (1992). Institutional uncertainty and taxpayer compliance. American Economic Review, 66(3):577-593

Asian Development Bank (2009). Asian Development Outlook, Rebalancing Asia's Growth. Retrieved 13 ${ }^{\text {th }}$ March, 2009.

Azubike, K. (2009). Marginal tax and its effects on the economy. Nigeria Journal of Economic and socio studies, 91(3):45-58

Beck, P. J. and Davis, J. S. (1991). Experimental evidence on taxpayer reporting under uncertainty. Accounting Review, 66(3):535-558.

Braithwaith, V. (2007). Taxation and Good Governance. University House Lecture and House Dinner series, Australian National University, Canberra, 118p.

Chan, C. W. Troutman, C. T. and O'Bryan, D. (2000). An expanded model of taxpayer compliance: Empirical evidence from United States and Hong Kong. Journal of International Accounting, Auditing and Taxation, 9(2):83-103. 
Christian, C. and Gupta, S. (1993). New evidence on Secondary evasion Journal of the American Taxation Association, 15(1):72-93

Etim, E. O. and Nweze, A. O. (2015). Taxation Review and Economic growth in Nigeria from 1980-2013. Tropical series, 23(2):46-67.

Fatt, C. K. and Klrin, E. (2012). The impact of organizational justice on Tax compliance behaviour. India International Journal of Psychology, 3(1):46-61

Harris, T. D. (1989). The effect of type of tax knowledge on individuals perceptions of fairness and compliance with the Federal Income Tax System: An empirical study. Ph.D Thesis, University of South Carolina, 210p.

Hite, P. (1997). Identifying and Mitigating Taxpayer Compliance. Australian Tax Forum, 13:155-180.

International Monetary Fund (IMF) (2015). Revenue Mobilization of Developing countries, IMF, Washington DC, retrieved 15th March, 2020.

Jackson, B. R. and Milliron, V.C (1986). Tax compliance research findings problems and prospects. Journal of Accounting Literature, 5:125-165.

Kasipillai, J. (2001). Understanding Self-Assessment: Taxpayer's perspective. Journal of Tax Conference, 8:91-113.

Kirchler, E., Hoelzl, E. and Wahl, I. (2008). Enforced versus Voluntary Compliance: The "Slippery Slope" framework. Journal of Economic Psychology, 29:210-255.

Lewis, A. (1982). The Psychology of Taxation Oxford: Martin Robertson.

Loo, E. C. (2006), The influence of the introduction on Self-Assessment on Compliance behaviour of individual taxpayers in Malaysia, Ph.D Thesis, University of Sydney.

Lubian, D. and Zarri, L. (2011). Happiness and Tax Morale: An Empirical Analysis. Working paper series, Department of Economics, University of Verona.

Lymer, A. and Oats, L. (2008). Taxation: Policy and Practice (16th Ed.). Birmingham: Fiscal Publication, 3(2):214 - 231

Mohani, A. (2001). Personal Income Tax Non-compliance in Malaysia, Ph.D Thesis, Victoria University Melbourne.

Nzotta, S. M. (2007). Tax evasion problems in Nigeria: A Critique. The Nigerian Accountant, 29(1):40-43.

Oladipupo, A. O. and Obazee, U. (2016). Tax Knowledge, Penalties and Tax Compliance in Small and Medium Scales Enterprises in Nigeria, I-Business, 8:1-9.

Paul, M. R. (2010). Tax knowledge and Tax Compliance Determines in Self-Assessment System in Malaysia. University of Birmingham Research Achieve. E-thesis repository.

Park, C. and Hyn, J. K. (2003). Examining the determinants of tax compliance by experimenting data: A case of Korea. Journal of Policy Modeling, 25:673-684.

Richardson, G. (2008). The impact of tax fairness dimensions on tax compliance behaviour behaviour in Asian jurisdiction: The case of Hong Kong. International Tax Journal, Winter, 29-42.

Ritsema, C. M., Thomas, D. W. and Ferrier, G. D. (2003). Economic and Behavioural Determinants of Tax Compliance: evidence from the 1997 Arkansas tax penalty amnesty program, paper prosecute at the IRS Research Conference, June. Retrieved 11th March, 2020.

Roth, J. A., School, J.T. and Witte, A. D. (1989) Taxpayer compliance: An Empirical Investigation of Selected States in Nigeria. Journal of Poverty, Investment and Development, 4:102-114.

Singh, V. (2003). Tax Compliance and ethical decision-making: A Malaysia perspective, (3rd ed.) Petaling Jaya: Longman.

Song, Y. D. and Yarbrough, T. E. (1978). Tax ethics and Taxpayer Attitude: Public Administration Review, 38(5):442452.

Spicer, M. W. and Becker, L. M. (1980). Fiscal Integrity and Tax evasion; An Experimental Approach. National Tax Journal, 33(2): 171-175. 
Umoffong, N. J., Etim, E. O., \& Bassey, O. D. (2020). Demographic and Socio-Economic Factorts as Determinants of Tax Complaince in SelfAssessment System (Sas) In Akwa Ibom State, Nigeria. Archives of Business Research, 8(5). 112-136.

Spicer, M. W. and Lundstedt, S. B. (1976). Understanding tax evasion. Public Finance, 31 (2):295-305.

Tanzi, V. and Zee, H. H. (2000). Tax Policy for emerging markets: Developing Countries, IMF Working papers, WP/00/35:1-34.

Torgler, B. (2007). Tax Compliance and Tax morale: A Theoretical and empirical Analysis, Cheltenham: E. E.

Torgler, B. and Schneider, F. (2007). Attitudes towards paying taxes is paying taxers in Austria: An Empirical Analysis. Empirical, 32(2):231-246.

Tyler, T. and Lind, E. (1992). A Relational Model of authority in groups. In Zanna, M. P. (ed). Advances in Experimental Social Psychology, XXV: 115-119.

Wallschutzy, I. G. (1984). Possible Causes of Tax Evasion. Journal of Economic Psychology, 5:371-384.

Wearing, A and Heady, B. (1997). The would-tax-evader. A profile. Australian Tax Forum, 13:3-17.

Wenzel, M. (2003). An analysis of norm processes in tax compliance. Journal of Economic Psychology, 25 (2):213-228.

Witte, A. and Woodbury, D. F. (2011). What we know about the factors affecting compliance with the tax laws. A report of the ABA section of Taxation Invitational Conference on Income Tax Compliance, 133-148.

Wilson, H. and Sheffin, D. (2005). Cross-country tax revenue comparisions. World Development, 24 (10):1659-71. 


\section{APPENDIX}

\section{A. PERCEPTION OF EQUITY AND FAIRNESS}

I perceive that I pay the same amount of taxes as others in the same income class that is why I oblige to completing my tax returns.

\begin{tabular}{|ll|l|l|l|l|}
\hline & & $\begin{array}{l}\text { Frequenc } \\
\mathrm{y}\end{array}$ & Percent & $\begin{array}{l}\text { Valid } \\
\text { Percent }\end{array}$ & $\begin{array}{l}\text { Cumulative } \\
\text { Percent }\end{array}$ \\
\hline \multirow{4}{*}{ DISAGREE } & STRONG & 74 & 19.0 & 19.0 & 19.0 \\
& & 80 & 20.6 & 20.6 & 39.6 \\
& DISAGREE & 84 & 21.6 & 21.6 & 61.2 \\
& UNDECIDED & & & & \\
& & 87 & 22.4 & 22.4 & 83.5 \\
& AGREE & 64 & 16.5 & 16.5 & 100.0 \\
& STRONGLY AGREE & 389 & 100.0 & 100.0 & \\
& Total & & & & \\
& & & & & \\
\hline
\end{tabular}

There is no equity and fairness in tax administration that is why I don't file my tax returns.

\begin{tabular}{|ll|l|l|l|l|}
\hline & & $\begin{array}{l}\text { Frequenc } \\
\mathrm{y}\end{array}$ & Percent & $\begin{array}{l}\text { Valid } \\
\text { Percent }\end{array}$ & $\begin{array}{l}\text { Cumulative } \\
\text { Percent }\end{array}$ \\
\hline \multirow{5}{*}{ DISAGREE } & STRONG & 73 & 18.8 & 18.8 & 18.8 \\
& & 91 & 23.4 & 23.4 & 42.2 \\
& DISAGREE & 46 & 11.8 & 11.8 & 54.0 \\
& UNDECIDED & & & & \\
& & 65 & 16.7 & 16.7 & 70.7 \\
& AGREE & 114 & 29.3 & 29.3 & 100.0 \\
& STRONGLY AGREE & 389 & 100.0 & 100.0 & \\
& Total & & & & \\
\hline
\end{tabular}

I do not manipulate my tax due and other records because I perceive the system is fair to taxpayers.

\begin{tabular}{|ll|l|l|l|l|}
\hline & & $\begin{array}{l}\text { Frequenc } \\
\mathrm{y}\end{array}$ & Percent & $\begin{array}{l}\text { Valid } \\
\text { Percent }\end{array}$ & $\begin{array}{l}\text { Cumulative } \\
\text { Percent }\end{array}$ \\
\hline \multirow{4}{*}{ DISAGREE } & STRONG & 57 & 14.7 & 14.7 & 14.7 \\
& & 69 & 17.7 & 17.7 & 32.4 \\
& DISAGREE & 72 & 18.5 & 18.5 & 50.9 \\
& UNDECIDED & 113 & 29.0 & 29.0 & 79.9 \\
& & 78 & 20.1 & 20.1 & 100.0 \\
& AGREE & 100.0 & 100.0 & \\
& STRONGLY AGREE & 389 & & & \\
& Total & & & & \\
\end{tabular}


Umoffong, N. J., Etim, E. O., \& Bassey, O. D. (2020). Demographic and Socio-Economic Factorts as Determinants of Tax Complaince in SelfAssessment System (Sas) In Akwa Ibom State, Nigeria. Archives of Business Research, 8(5). 112-136.

By paying the right amount of tax, I believe the citizens will get the benefit through the provision of basic amenities by government.

\begin{tabular}{|ll|l|l|l|l|}
\hline & & $\begin{array}{l}\text { Frequenc } \\
\mathrm{y}\end{array}$ & Percent & $\begin{array}{l}\text { Valid } \\
\text { Percent }\end{array}$ & $\begin{array}{l}\text { Cumulative } \\
\text { Percent }\end{array}$ \\
\hline \multirow{5}{*}{ DISAGREE } & STRONG & 54 & 13.9 & 13.9 & 13.9 \\
& & 95 & 24.4 & 24.4 & 38.3 \\
& DISAGREE & 65 & 16.7 & 16.7 & 55.0 \\
& UNDECIDED & & & & \\
& & 106 & 27.2 & 27.2 & 82.3 \\
& AGREE & 69 & 17.7 & 17.7 & 100.0 \\
& STRONGLY AGREE & 389 & 100.0 & 100.0 & \\
& Total & & & & \\
\hline
\end{tabular}

B. INCOME LEVEL

I pay the required tax rate authority irrespective of my income level.

\begin{tabular}{|ll|l|l|l|l|}
\hline & & $\begin{array}{l}\text { Frequenc } \\
\mathrm{y}\end{array}$ & Percent & $\begin{array}{l}\text { Valid } \\
\text { Percent }\end{array}$ & $\begin{array}{l}\text { Cumulative } \\
\text { Percent }\end{array}$ \\
\hline \multirow{5}{*}{ DISAGREE } & STRONG & 58 & 14.9 & 14.9 & 14.9 \\
& & 38 & 9.8 & 9.8 & 24.7 \\
& DISAGREE & 99 & 25.7 & 25.7 & 50.1 \\
& UNDECIDED & & & & \\
& & 100 & 24.2 & 24.2 & 75.8 \\
& AGREE & 94 & 16.5 & 16.5 & 100.0 \\
& STRONGLY AGREE & 389 & 100.0 & 100.0 & \\
& Total & & & & \\
\hline
\end{tabular}

Lower tax rate is being charged on my higher income that is why I obliged to timely returns.

\begin{tabular}{|ll|l|l|l|l|}
\hline & & $\begin{array}{l}\text { Frequenc } \\
\mathrm{y}\end{array}$ & Percent & $\begin{array}{l}\text { Valid } \\
\text { Percent }\end{array}$ & $\begin{array}{l}\text { Cumulative } \\
\text { Percent }\end{array}$ \\
\hline \multirow{4}{*}{ DISAGREE } & STRONG & 68 & 17.5 & 17.5 & 17.5 \\
& & 75 & 19.3 & 19.3 & 36.8 \\
& DISAGREE & 28 & 7.2 & 7.2 & 44.0 \\
& UNDECIDED & & & & \\
& & 52 & 13.4 & 13.4 & 57.3 \\
& AGREE & 166 & 42.7 & 42.7 & 100.0 \\
& STRONGLY AGREE & 389 & 100.0 & 100.0 & \\
& Total & & & & \\
\hline
\end{tabular}


Higher tax rate is being charged on the meager income that is why I don't file my returns.

\begin{tabular}{|ll|l|l|l|l|}
\hline & & $\begin{array}{l}\text { Frequenc } \\
\mathrm{y}\end{array}$ & Percent & $\begin{array}{l}\text { Valid } \\
\text { Percent }\end{array}$ & $\begin{array}{l}\text { Cumulative } \\
\text { Percent }\end{array}$ \\
\hline \multirow{3}{*}{ DISAGREE } & STRONG & 43 & 11.1 & 11.1 & 11.7 \\
& & 72 & 18.5 & 18.5 & 29.6 \\
& DISAGREE & 55 & 14.1 & 14.1 & 43.7 \\
Valid & UNDECIDED & 100 & 25.7 & 25.7 & 69.4 \\
& & 119 & 30.6 & 30.6 & 100.0 \\
& AGREE & 100.0 & 100.0 & \\
& STRONGLY AGREE & 389 & & & \\
\hline & Total & & &
\end{tabular}

My expenditure always exceeds my income that is why I don't file my returns.

\begin{tabular}{|ll|l|l|l|l|}
\hline & & $\begin{array}{l}\text { Frequenc } \\
\mathrm{y}\end{array}$ & Percent & $\begin{array}{l}\text { Valid } \\
\text { Percent }\end{array}$ & $\begin{array}{l}\text { Cumulative } \\
\text { Percent }\end{array}$ \\
\hline \multirow{3}{*}{ DISAGREE } & STRONG & 51 & 13.1 & 13.1 & 13.1 \\
& & 90 & 23.1 & 23.1 & 36.2 \\
& DISAGREE & 81 & 20.8 & 20.8 & 57.1 \\
Valid & UNDECIDED & 88 & 22.6 & 22.6 & 79.7 \\
& & 79 & 20.3 & 20.3 & 100.0 \\
& AGREE & 100.0 & 100.0 & \\
& STRONGLY AGREE & 389 & & & \\
& Total & & &
\end{tabular}


Umoffong, N. J., Etim, E. O., \& Bassey, O. D. (2020). Demographic and Socio-Economic Factorts as Determinants of Tax Complaince in SelfAssessment System (Sas) In Akwa Ibom State, Nigeria. Archives of Business Research, 8(5). 112-136.

\section{LEVEL OF EDUCATION}

I have never obtained any training on the Self-Assessment System tax laws and its procedures.

\begin{tabular}{|ll|l|l|l|l|}
\hline & & $\begin{array}{l}\text { Frequenc } \\
\text { y }\end{array}$ & Percent & $\begin{array}{l}\text { Valid } \\
\text { Percent }\end{array}$ & $\begin{array}{l}\text { Cumulative } \\
\text { Percent }\end{array}$ \\
\hline \multirow{3}{*}{ DISAGREE } & STRONG & 22 & 5.7 & 5.7 & 5.7 \\
& & 16 & 4.1 & 4.1 & 9.8 \\
& DISAGREE & 34 & 8.7 & 8.7 & 18.5 \\
Valid & UNDECIDED & & & & \\
& & 204 & 52.4 & 52.4 & 71.0 \\
& AGREE & 113 & 29.0 & 29.0 & 100.0 \\
& STRONGLY AGREE & 389 & 100.0 & 100.0 & \\
& Total & & & \\
\hline
\end{tabular}

I have obtained adequate training on Self-Assessment System of tax and can compute my tax liabilities and file in my returns accurately without assistance.

\begin{tabular}{|ll|l|l|l|l|}
\hline & & $\begin{array}{l}\text { Frequenc } \\
\text { y }\end{array}$ & Percent & $\begin{array}{l}\text { Valid } \\
\text { Percent }\end{array}$ & $\begin{array}{l}\text { Cumulative } \\
\text { Percent }\end{array}$ \\
\hline \multirow{5}{*}{ DISAGREE } & STRONG & 57 & 14.7 & 14.7 & 14.7 \\
& & 58 & 14.9 & 14.9 & 29.6 \\
& DISAGREE & 21 & 5.4 & 5.4 & 35.0 \\
& UNDECIDED & 79 & 20.3 & 20.3 & 55.3 \\
& & 174 & 44.7 & 44.7 & 100.0 \\
& AGREE & 100.0 & 100.0 & \\
& STRONGLY AGREE & 389 & 100.0 & \\
& Total & & & & \\
\hline
\end{tabular}

I know how to keep records/documents pertaining to income and expenditure for a certain period after submission of tax return.

\begin{tabular}{|ll|l|l|l|l|}
\hline & & $\begin{array}{l}\text { Frequenc } \\
\mathrm{y}\end{array}$ & Percent & $\begin{array}{l}\text { Valid } \\
\text { Percent }\end{array}$ & $\begin{array}{l}\text { Cumulative } \\
\text { Percent }\end{array}$ \\
\hline \multirow{5}{*}{ DISAGREE } & STRONG & 28 & 7.2 & 7.2 & 7.2 \\
& & 39 & 10.0 & 10.0 & 17.2 \\
& DISAGREE & 28 & 7.2 & 7.2 & 24.4 \\
& UNDECIDED & & & & \\
& & 109 & 28.0 & 28.0 & 52.4 \\
& AGREE & 185 & 47.6 & 47.6 & 100.0 \\
& STRONGLY AGREE & 389 & 100.0 & 100.0 & \\
& Total & & & & \\
\hline
\end{tabular}


I know which income should be included in determining the taxable income.

\begin{tabular}{|ll|l|l|l|l|}
\hline & & $\begin{array}{l}\text { Frequenc } \\
\mathrm{y}\end{array}$ & Percent & $\begin{array}{l}\text { Valid } \\
\text { Percent }\end{array}$ & $\begin{array}{l}\text { Cumulative } \\
\text { Percent }\end{array}$ \\
\hline \multirow{3}{*}{ DISAGREE } & STRONG & 38 & 9.8 & 9.8 & 9.8 \\
& & 76 & 19.5 & 19.5 & 29.3 \\
& DISAGREE & 38 & 9.8 & 9.8 & 39.1 \\
Valid & UNDECIDED & 137 & 35.2 & 35.2 & 74.3 \\
& & 100 & 25.7 & 25.7 & 100.0 \\
& AGREE & 100.0 & 100.0 & \\
& STRONGLY AGREE & 389 & & & \\
\hline & Total & & &
\end{tabular}

D. TAX COMPLIANCE

I am a registered tax payer with Tax Identity Number.

\begin{tabular}{|ll|l|l|l|l|}
\hline & & $\begin{array}{l}\text { Frequenc } \\
\mathrm{y}\end{array}$ & Percent & $\begin{array}{l}\text { Valid } \\
\text { Percent }\end{array}$ & $\begin{array}{l}\text { Cumulative } \\
\text { Percent }\end{array}$ \\
\hline \multirow{3}{*}{ DISAGREE } & STRONG & 64 & 16.5 & 16.5 & 16.5 \\
& & 61 & 15.7 & 15.7 & 32.1 \\
& DISAGREE & 94 & 24.2 & 24.2 & 56.3 \\
Valid & UNDECIDED & 60 & 15.4 & 15.4 & 71.7 \\
& & 110 & 28.3 & 28.3 & 100.0 \\
& AGREE & 100.0 & 100.0 & \\
& STRONGLY AGREE & 389 & & & \\
\hline & Total & & & \\
\end{tabular}

I file my tax returns and meet the entire requirement by the due date.

\begin{tabular}{|ll|l|l|l|l|}
\hline & & $\begin{array}{l}\text { Frequenc } \\
\text { y }\end{array}$ & Percent & $\begin{array}{l}\text { Valid } \\
\text { Percent }\end{array}$ & $\begin{array}{l}\text { Cumulative } \\
\text { Percent }\end{array}$ \\
\hline \multirow{3}{*}{ DISAGREE } & STRONG & 41 & 10.5 & 10.5 & 10.5 \\
& & 91 & 23.4 & 23.4 & 33.9 \\
& DISAGREE & 76 & 19.5 & 19.5 & 53.5 \\
Valid & UNDECIDED & & & & \\
& & 55 & 14.1 & 14.1 & 67.6 \\
& AGREE & 126 & 32.4 & 32.4 & 100.0 \\
& STRONGLY AGREE & 389 & 100.0 & 100.0 & \\
& Total & & & \\
\hline
\end{tabular}


Umoffong, N. J., Etim, E. O., \& Bassey, O. D. (2020). Demographic and Socio-Economic Factorts as Determinants of Tax Complaince in SelfAssessment System (Sas) In Akwa Ibom State, Nigeria. Archives of Business Research, 8(5). 112-136.

I correctly report tax liabilities.

\begin{tabular}{|ll|l|l|l|l|}
\hline & & Frequenc & Percent & $\begin{array}{l}\text { Valid } \\
\text { Percent }\end{array}$ & $\begin{array}{l}\text { Cumulative } \\
\text { Percent }\end{array}$ \\
\hline \multirow{4}{*}{ DISAGREE } & STRONG & 18 & 4.6 & 4.6 & 4.6 \\
& & 59 & 15.2 & 15.2 & 19.8 \\
& DISAGREE & 105 & 27.0 & 27.0 & 46.8 \\
& UNDECIDED & & & & \\
& & 111 & 28.5 & 28.5 & 75.3 \\
& AGREE & 96 & 24.7 & 24.7 & 100.0 \\
& STRONGLY AGREE & 389 & 100.0 & 100.0 & \\
& Total & & & & \\
\hline
\end{tabular}

I pay taxes on time, mostly by the date stipulated in the law.

\begin{tabular}{|ll|l|l|l|l|}
\hline & & $\begin{array}{l}\text { Frequenc } \\
\mathrm{y}\end{array}$ & Percent & $\begin{array}{l}\text { Valid } \\
\text { Percent }\end{array}$ & $\begin{array}{l}\text { Cumulative } \\
\text { Percent }\end{array}$ \\
\hline \multirow{3}{*}{ DISAGREE } & STRONG & 22 & 5.7 & 5.7 & 5.7 \\
& & 72 & 18.5 & 18.5 & 24.2 \\
& DISAGREE & 106 & 27.2 & 27.2 & 51.4 \\
Valid & UNDECIDED & 139 & 35.7 & 35.7 & 87.1 \\
& & 50 & 12.9 & 12.9 & 100.0 \\
& AGREE & 100.0 & 100.0 & \\
& STRONGLY AGREE & 389 & & & \\
& Total & & & & \\
\end{tabular}


APPENDIX - QUESTIONNAIRE SAMPLE

Instruction: Tick the appropriate box below.

1. Highest Educational Level: (a) SSCE [ ] (b) NCE/ND [ ] (c) BSc/HND [ ] MSc/MBA/PGD [ ] (e) Others (specify)

2. Number of years in occupation/profession: (a) Below 5 years [ ] (b) 5-10 years [ ] (c) 11-15 years [ ] (d) 16 years and above [ ]

\begin{tabular}{|c|c|c|c|c|c|c|}
\hline \multicolumn{7}{|c|}{ A. PERCEPTION OF EQUITY AND FAIRNESS $\left(\mathrm{X}_{1}\right)$} \\
\hline $\begin{array}{l}\mathrm{S} / \\
\mathrm{N}\end{array}$ & ITEMS & SA & A & UN & $\mathrm{D}$ & SD \\
\hline 1 & $\begin{array}{l}\text { I perceive that I pay the sum amount of taxes as others in the } \\
\text { same income class that is why I oblige to completing my tax } \\
\text { returns. }\end{array}$ & & & & & \\
\hline 2 & $\begin{array}{l}\text { There is no equity and fairness in tax administration that is why } \\
\text { I don't file my tax returns. }\end{array}$ & & & & & \\
\hline 3 & $\begin{array}{l}\text { I do not manipulate my tax due and other records because I } \\
\text { perceive the system is fair to taxpayers. }\end{array}$ & & & & & \\
\hline 4 & $\begin{array}{l}\text { By paying the right amount of tax. I believe the citizens will get } \\
\text { the benefit through the provision of basic amenities by } \\
\text { government. }\end{array}$ & & & & & \\
\hline
\end{tabular}

\section{DEMOGRAPHIC FACTORS}

\begin{tabular}{|l|l|l|l|l|l|l|}
\hline B. INCOME LEVEL $\left.\quad \mathbf{X}_{2}\right)$ & SA & A & UN & D & SD \\
\hline S/ & ITEMS & $\begin{array}{l}\text { I pay the required tax rate to authority irrespective of my income } \\
\text { level }\end{array}$ & & & \\
\hline 2 & $\begin{array}{l}\text { Lower tax rate is being charged on my higher income that is why } \\
\text { Iobliged to timely returns. }\end{array}$ & & & & \\
\hline 3 & $\begin{array}{l}\text { High tax rate is been charged on my meager income that is why } \\
\text { I don't file my returns. }\end{array}$ & & & & \\
\hline 4 & $\begin{array}{l}\text { My expenditure always exceeds my income that is why I don't } \\
\text { file my returns. }\end{array}$ & & & \\
\hline
\end{tabular}

\begin{tabular}{|l|l|l|l|l|l|l|}
\hline C. LEVEL OF EDUCATION $\left(\mathbf{X}_{\mathbf{3}}\right)$ & SA & AN & D & SD \\
\hline 1 & $\begin{array}{l}\text { ITEMS } \\
\text { I have never obtained any training on the Self-Assessment } \\
\text { System tax laws and its procedure. }\end{array}$ & $\begin{array}{l}\text { I have obtained adequate training on Self-Assessment System of } \\
\text { tax and can compute my tax liabilities and file in my accurately } \\
\text { without any assistance. }\end{array}$ & $\begin{array}{l}\text { I know how to keep records/documents pertaining to income } \\
\text { and expenditure for a certain period after submission of tax } \\
\text { return. }\end{array}$ & $\begin{array}{l}\text { I know which income should be included or excluded in } \\
\text { determining the taxable income. }\end{array}$ & & \\
\hline 3
\end{tabular}


Umoffong, N. J., Etim, E. O., \& Bassey, O. D. (2020). Demographic and Socio-Economic Factorts as Determinants of Tax Complaince in SelfAssessment System (Sas) In Akwa Ibom State, Nigeria. Archives of Business Research, 8(5). 112-136.

DEPENDENT VARIABLE

\begin{tabular}{|l|l|l|l|l|l|l|}
\hline \multicolumn{2}{|l|}{ D. COM COMPIANCE (Y) } & SA & A & UN & D & SD \\
\hline $\begin{array}{l}\text { S/ } \\
\text { ITEMS }\end{array}$ & & & & & \\
\hline 1 & I am a registered tax payer with Tax Identification Number. & & & \\
\hline 2 & $\begin{array}{l}\text { I file my tax returns and meet the entire requirement by the due } \\
\text { date. }\end{array}$ & & & & & \\
\hline 3 & I correctly report tax liabilities. & & & & \\
\hline 4 & $\begin{array}{l}\text { I pay taxes on time that is, mostly by the date stipulated in the } \\
\text { law. }\end{array}$ & & & \\
\hline
\end{tabular}

